\title{
EVALUASI HEMATOTOKSIK SECARA IN VITRO NANOPARTIKEL ZnS HASIL REDUKSI BIOMATRIKS Eschericia coli
}

\author{
Lisa Kurniati, Andi Arjuna, dan Sukamto S. Mamada \\ Fakultas Farmasi, Universitas Hasanuddin, Makassar, Indonesia
}

Kata Kunci :

E. coli,

hematotoksisitas, in vitro, nanopartikel ZnS

\begin{abstract}
ABSTRAK
Nanopartikel ZnS merupakan material semi konduktor yang memiliki sifat unik dan manfaat yang besar dibidang kesehatan, terutama sebagai antibakteri dan biomarker kanker. Walaupun demikian, informasi mengenai toksisitas dari nanopartikel $\mathrm{ZnS}$ masih sangat terbatas. Oleh karena itu, pada penelitian ini telah dilakukan evaluasi hematotoksisitas secara in vitro nanopartikel $\mathrm{ZnS}$ hasil reduksi biomatriks Escherichia coli. Penyiapan nanopartikel ZnS diawali dengan pencampuran dispersi ZnSO4 konsentrasi 200 bpj ke dalam medium Luria Bertani Broth (LBB) yang ditumbuhi E.Coli sebagai bioreduktor. Produk yang dihasilkan dikarakterisasi dengan uji photolimunisence (PL) dan spektrofotometri pada rentang panjang gelombang $250-700 \mathrm{~nm}$. Hasilnya, nanopartikel $\mathrm{ZnS}$ berpendar biru dan diidentifikasi pada $\lambda$ max $288 \mathrm{~nm}$ dengan absorbansi 0,905. Partikel yang dihasilkan kemudian didispersikan dengan variasi volume $30 \mu \mathrm{l}, 40 \mu \mathrm{l}, 50 \mu \mathrm{l}$ pada larutan tyrod. Data persentase hemolisis secara berturut-turut adalah $32 \%, 39 \%, 22 \%, 0 \%$ (kontrol negatif) dan 100\% (kontrol positif). Sehingga dapat disimpulkan bahwa nanopartikel ZnS hasil reduksi E.coli memberikan efek toksik terhadap sel darah merah.
\end{abstract}

\section{PENDAHULUAN}

Nanopartikel seng sulfida (ZnS) adalah bahan semikonduktor yang diketahui memiliki sifat yang unik sehingga banyak peneliti yang tertarik untuk melakukan penelitian terkait hal tersebut (1). Misalnya pada penelitian evaluasi kemampuan mendiagnosis biomarker kanker prostat miR-141 menggunakan CdSe/ZnS (2). Dalam beberapa penelitian, nanopartikel ZnS juga memiliki aktivitas yang sangat baik sebagai antibakteri dan sebagai biomarker kanker (3).

Secara umum, untuk sintesis nanomaterial $\mathrm{ZnS}$ dapat menggunakan metode fisika-kimia, tetapi pada metode tersebut membutuhkan suhu dan tekanan yang tinggi, reagen yang berbahaya, bahan baku yang mahal dan proses yang rumit (4).

Oleh karena itu, penggunaan mikroorganisme dan atau tanaman menjadi pilihan karena ramah lingkungan, contohnya menggunakan bakteri (4).

Berdasarkan penelitian oleh Wahyu Dirgantarah dkk, nanopartikel ZnS dapat diproduksi dengan menggunakan agen pereduksi bakteri Escherichia coli. Nanopartikel ZnS yang dihasilkan berupa dispersi koloidal dengan diameter partikel ratarata 9,175 $\mathrm{nm}(5)$.

Walaupun nanopartikel ZnS yang dihasilkan dapat menjadi kandidat biomarker. Informasi tentang keamanan dan toksisitas masih sangat terbatas. Padahal pada beberapa studi, nanomaterial menunjukkan potensi sitotoksik, kerusakan DNA, dan stres oksidatif yang berpusat pada nanopartikel logam (6). ZnS pun dapat menyebabkan hemolisis pada sel darah merah (7).

Berdasarkan uraian di atas, maka peneliti tertarik untuk melakukan pengujian efekhematotoksisitas dari nanopartikel ZnS hasil reduksi biomatriks bakteri E. coli dengan melihat efeknya terhadap sel darah merah. Hasil penelitian ini diharapkan menjadi informasi ilmiah tentang keamanan dari nanopartikel ZnS hasil reduksi biomatriks $E$.coli terhadap sel darah merah manusia.

\section{METODE PENELITIAN}

\section{Penyiapan Sampel \\ Penyiapan seed liquid}

Dimasukkan komposisi media LBB (peptone 300 $\mathrm{mg}$, yeast extract $130 \mathrm{mg}, \mathrm{NaCl} 300 \mathrm{mg}$ ) ke dalam erlenmeyer $100 \mathrm{ml}$ yang berisi air suling $30 \mathrm{ml}$ dan ditambahkan larutan glukosa $20 \%$ steril $0,3 \mathrm{ml}$. Dilakukan proses sterilisasi medium dengan menggunakan autoklaf, suhu $121^{\circ} \mathrm{C}$, tekanan $1 \mathrm{~atm}$ selama 15 menit.

\section{Penyiapan suspensi Escherichia coli}

Biakan murni bakteri E. coli disuspensikan menggunakan air steril $5 \mathrm{ml}$ secara aseptis sebelum melakukan proses inokulasi ke dalam seed liquid.

\section{Tahap Produksi}

\section{Kultivasi seed liquid}

Dimasukkan $1 \mathrm{ml}$ suspensi bakteri E. coli ke dalam seed liquid kemudian dikultivasi selama 7 jam (fase pertumbuhan logaritma) pada thermostat incubator suhu $37^{\circ} \mathrm{C}$ yang dishaker $250 \mathrm{rpm}$.

\section{Penyiapan larutan Zink Sulfat}

Dilarutkan $40 \mathrm{mg} \mathrm{ZnSO}_{4}$ ke dalam $100 \mathrm{ml}$ air steril yang kemudian ditambahkan ke dalam media LBB $100 \mathrm{ml}$ untuk memperoleh konsentrasi larutan 200 bpj (konsentrasi tertinggi dibawah nilai KHM yang telah diperoleh sebelumnya) secara aseptis. 


\section{Produksi Nanopartikel ZnS}

Disiapkan $100 \mathrm{ml}$ media LBB segar dalam erlemeyer $500 \mathrm{ml}$. Selanjutnya $1 \mathrm{ml}$ seed liquid (kultivasi 7 jam) dimasukkan ke dalam media LBB segar tersebut untuk proses kultivasi selama 10jam (fase pertumbuhan stasioner) dengan perlakuan yang sama pada tahap pembuatan seed liquid. Kemudian hasil kultivasi tersebut ditambahkan larutan garam $\mathrm{ZnSO}_{4}$ yang telah disiapkan. Disertakan medium LBB kontrol dengan tidak menambahkan $\mathrm{ZnSO}_{4}$ ke dalamnya. Setelah penambahan $\mathrm{ZnSO}_{4}$ tersebut, biakan diinkubasi kembali selama satu hari (1x24 jam) dan dishaker dengan kecepatan $250 \mathrm{rpm}$ pada suhu $37^{\circ} \mathrm{C}$ dari prosedur tersebut akan diperoleh nanopartikel $\mathrm{ZnS}$ dengan bantuan biomatriks bakteri E. coli.

\section{Evaluasi Nanopartikel Zink Sulfida}

\section{Pengamatan Pendaran}

Setelah proses produksi, media LBB yang mengandung $E$. coli disentrifugasi pada kecepatan $6000 \mathrm{rpm}$ selama 10 menit untuk memecah sel bakteri bersama protein medium dan mengendapkannya. Supernatan kemudian diambil untuk dilakukan pengamatan photoluminence dibawah lampu UV.

\section{Pengukuran Panjang Gelombang dengan menggunakan} spektrofotometer UV-Vis

Supernatan yang telah diamati kemampuan flurosensinya selanjutnya diukur menggunakan spektrofotometer UV-Vis untuk mengetahui panjang gelombang maksimumnya ( $\lambda$ maks). Scanning dilakukan mulai dari panjang gelombang $250 \mathrm{~nm}$ hingga $700 \mathrm{~nm}$.

\section{Evaluasi Hematotoksisitas Nanopartikel ZnS}

Sebanyak $2 \mathrm{ml}$ darah yang diambil di Unit Tranfusi Darah (UTD) Kota Makassar dengan nomor seri F0830118a dicampur dengan PBS dengan volume $2 \mathrm{ml}$ lalu disentrifugasi dengan kecepatan $6000 \mathrm{rpm}$ selama 10 menit sehingga diperoleh larutan berupa pelet yang mengandung sel darah merah. Pelet selanjutnya dibersihkan dengan PBS disentrifugasi dengan kecepatan $6000 \mathrm{rpm}$ selama 3 menit. Pembersihan ini dilakukan 3 kali sampai diperoleh sel darah merah murni. Sel darah merah murni kemudian didispersikan dengan PBS dengan perbandingan 1:10 Nanopartikel ZnS didispersikan dengan larutan tyrod dengan volume larutan 1:1 pada variasi konsentrasi larutan reduksi $\mathrm{ZnS} 30 \mu \mathrm{l}, 40 \mu \mathrm{l}$ dan $50 \mu \mathrm{l}$. Untuk pengujian hematotoksisitas, larutan tyrod murni digunakan sebagai kontrol negatif. Variasi volume nanopartikel diambil dan ditambahkan ke dalam $200 \mu \mathrm{l}$ sel darah merah murni. Larutan kemudian diinkubasi pada suhu kamar selama 12 jam. Selanjutnya diperoleh supernatan kemudian diukur dengan menggunakan microplate scanning spectrophotometer dengan panjang gelombang $510 \mathrm{~nm}$ untuk melihat absorbansi. Semakin tinggi absorbansi yang didapatkan maka semakin besar tingkat toksisitas nanopartikel ZnS dalam sel darah merah. Kemudian dianalisis data dan dihitung persentase kematian sel dengan menggunakan rumus:

$$
\mathrm{H} \%=\frac{\text { (OD Sampel-OD kontrol negatif) }}{\text { OD kontrol positif-OD Kontrol negatif }} \times 100 \%
$$

\section{Keterangan:}

1. $\mathrm{H} \%$ (Persentase kematian sel)

2. OD (Optical Density) sampel (ZnS)

3. OD (Optical Density) Kontrol negatif (tyrod)

4. OD (Optical Density) Kontrol positif $\left(\mathrm{ZnSO}_{4}\right)$

\section{Analisis Statistik}

Data yang diperoleh dianalisis menggunakan software SPSS 20 dengan metode Kolmonogorov-sminov untuk melihat distribusi data normal kemudian dilanjutkan dengan metode analisis one-way ANOVA kemudian dilanjutkan dengan uji post hoc dengan menggunakan uji signifikansi Boferroni. Pvalue $<0,05$ dinyatakan siginikan secara statistik.

\section{HASIL DAN PEMBAHASAN}

Sintesis nanopartikel ZnS pada penelitian ini menggunakan bahan pereduksi dari mikroorganisme yaitu dengan mereduksi $\mathrm{ZnSO}_{4}$ menjadi $\mathrm{ZnS}$ dengan menggunakan bakteri. Hasil sintesis yang dihasilkan berupa dispersi koloidal yang kemudian diuji photolimunisence atau uji PL untuk melihat pendaran dari larutan tersebut sebagai salah satu bentuk konfirmasi terbentuknya nanopartikel. Pengamatan pendaran dilakukan dibawah penyinaran lampu UV $366 \mathrm{~nm}$ pada waktu inkubasi $1 \times 24$ jam (1 hari), $2 \times 24$ jam (2 hari), $3 \times 24$ jam (3 hari), dan 4x24 jam (4 hari).

Berdasarkan penelitian Dirgantarah dkk pendaran yang paling kuat terjadi pada hari keempat hasil yang didapatkan menghasilkan pendaran berwarna biru yang berdasarkan rujuka penelitian menandakan telah terbentuknya nanopartikel $\mathrm{ZnS}$ dengan estimasi ukuran nanopartikel \pm 2 nm (8).

Untuk memperkuat dugaan terbentuknya nanopartikel dilanjutkan dengan pengukuran panjang gelombang 250-700 $\mathrm{nm}$ menggunakan spektrofotometer dapat dilihat pada Gambar 1. Pada grafik tersebut puncak serapan diidentifikasi pada panjang gelombang $288 \mathrm{~nm}$ dengan absorbansi 0,945 a.u. Hal ini menunjukkan kesesuaian rekomendasi teori bahwa nanopartikel $\mathrm{ZnS}$ terbentuk pada panjang gelombang dengan kisaran 200-400 nm $(5,9)$. Berdasarkan hasil dari spektra dan juga uji PL, nanopartikel ZnS diasumsikan telah terbentuk.

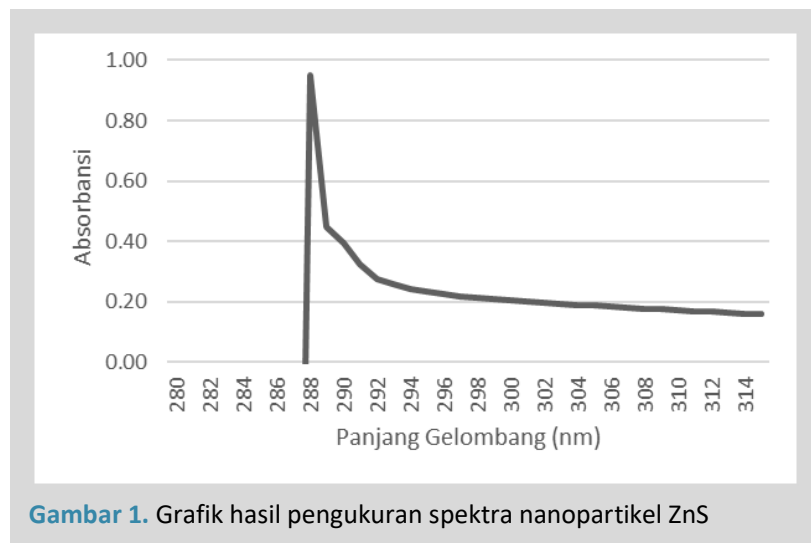

Selanjutnya dilakukan pengujian hematotoksisitas untuk mengetahui toksisitas nanopartikel $\mathrm{ZnS}$ terhadap sel darah merah. Berdasarkan data yang diperoleh pada Tabel 1, yang dianalisis statistik dengan menggunakan aplikasi SPSS (Statistical Package for the Social Sciences) yang kemudian dilakukan penentuan normalitas data dengan menggunakan uji Saphiro-Wilk data tersebut terdistribusi normal $(\mathrm{p}>0,05)$ dan uji levene juga mengonfirmasi bahwa varian data homogen $(\mathrm{p}>0,05)$.

Selanjutnya, dilakukan analisis dengan menggunakan One Way ANOVA yang $(\mathrm{p}<0,05)$ dan Uji post-hoc Bonferroni untuk melihat kelompok yang memiliki perbedaan yang nyata. Data tersebut dapat secara ringkas dilihat pada lampiran

Berdasarkan grafik persentase hemolisis pada Gambar 2 terlihat bahwa hasil pengujian tokisisitas nanopartikel ZnS hasil reduksi E.coli terhadap sel darah merah yang berbeda- 
Tabel 1. Hasil pengukuran toksisitas nanopartikel ZnS terhadap sel darah merah menggunakan microplate rider.

\begin{tabular}{|c|c|c|c|c|c|c|}
\hline Perlakuan & $\begin{array}{c}\text { Nanopartikel } 30 \\
\mu l(\%)\end{array}$ & $\begin{array}{c}\text { Nanopartikel } 40 \\
\mu \mathrm{l}(\%)\end{array}$ & $\begin{array}{c}\text { Nanopartikel } 50 \\
\mu l(\%)\end{array}$ & $\begin{array}{c}\text { Dispersi ZnSO4 } \\
\text { (\%) }\end{array}$ & K. Negatif (\%) & $\begin{array}{l}\text { K. Positif toksik } \\
\text { (\%) }\end{array}$ \\
\hline 1 & 33,137 & 48,555 & 22,337 & 12,075 & 0 & 100 \\
\hline 2 & 31,469 & 42,395 & 16,854 & 11,976 & 0 & 100 \\
\hline 3 & 37,670 & 32,981 & 22,823 & 5,948 & 0 & 100 \\
\hline 4 & 27,213 & 37,254 & 23,063 & 10,290 & 0 & 100 \\
\hline 5 & 28,147 & 33,770 & 25,443 & 7,233 & 0 & 100 \\
\hline Jumlah & 157,636 & 194,955 & 110,519 & 47,522 & 0 & 500 \\
\hline Rata-rata & 32 & 39 & 22 & 10 & 0 & 100 \\
\hline SD & 4,194 & 6,509 & 3,170 & 2,790 & 0 & 0 \\
\hline
\end{tabular}

beda dari variasi volume yang diberikan. Nanoparitkel ZnS hasil reduksi $E$. coli dari volume $30 \mu \mathrm{l}, 40 \mu \mathrm{l}$ dan $50 \mu \mathrm{l}$, dispersi $\mathrm{ZnSO}_{4}$ nanopartikel menunjukkan persentase hemolisis secara berurutan 32\%, 39\%, 22\% dan 10\% sedangkan pada kontrol negatif $0 \%$ dan kontrol positif $100 \%$. Dari hasil statistik menunjukkan bahwa dispersi $\mathrm{ZnSO}_{4}$ memiliki perbedaan nyata $(\mathrm{p}<0,05)$ dengan variasi volume nanoparitkel ZnS hasil reduksi E. coli dari volume V1 (30 $\mu \mathrm{l})$, V2 $(40 \mu \mathrm{l})$ dan V3 $(50 \mu \mathrm{l})$. Perbedaan nyata dengan peningkatan $\%$ hemolisis dipengaruhi oleh ukuran dari nanopartikel yang lebih kecil dibandingkan dengan dispersi $\mathrm{ZnSO}_{4}$.

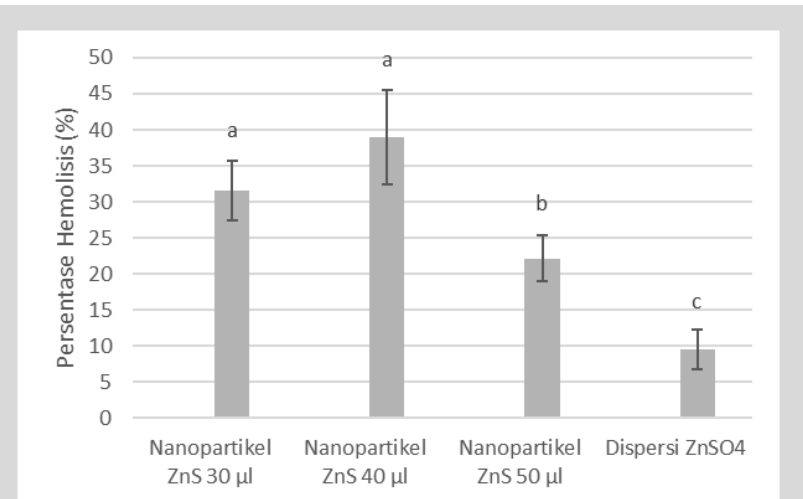

Gambar 2. Grafik Persentase Uji Hematotoksisitas

Keterangan:

1. \% Hemolisis dihitung berdasarkan perbandingan relatif terhadap kontro negatif ( $0 \%$ hemolisis) dan Kontrol positif ( $100 \%$ hemolisis).

2. Superscript yang berbeda menyatakan hubungan yang signifikan $(p<0,05)$.

Peningkatan \% hemolisis dipengaruhi oleh ukuran dari nanopartikel tersebut karena semakin berkurang ukuran partikelnya maka perbandingan luas permukaan dengan volume akan semakin meningkat. Hal ini menghasilkan area permukaan yang semakin besar sehingga daya penetrasinya akan lebih cepat (Sharifi, Shahriar dkk, 2012).

Pada variasi volume V1 $(30 \mu \mathrm{l})$ dan V2 $(40 \mu \mathrm{l})$ tidak menunjukkan perbedaan yang nyata sedangkan antara variasi volume V1 $(30 \mu \mathrm{l})$ dan V3 $(50 \mu \mathrm{l}), \mathrm{V} 2(40 \mu \mathrm{l})$ dan V3 $(50 \mu \mathrm{l})$ menunjukkan adanya perbedaan yang nyata. Dapat dilihat bahwa variasi volume yang kecil memiliki \% hemolisis yang lebih besar dibandingkan variasi volume yang besar hal ini kemungkinan terjadi disebabkan karena pada variasi V3 $(50 \mu \mathrm{l})$ memiliki konsentrasi yang lebih pekat yang diduga mengakibatkan perubahan secara fisika pada nanopartikel sehingga terjadi perubahan bentuk dan ukuran dari nanopatikel tersebut. Toksisitas yang terjadi dapat disebabkan oleh berbagai masalah seperti produksi ROS (Reactive oxygen species), pengurangan integritas membran, pelepasan logam toksik yang dapat berikatan dengan dengan resptor spesifik suatu sel, sehingga terjadi konformasi tertentu yang menyebabkan penghambatan fungsi sel normal yang berakibat pada sitotoksik, genotoksik dan kemungkinan terjadinya nekrosis pada sel. Ukuran nanopartikel yang kecil juga memiliki aktivitas yang sangat kuat sehingga semakin kecil partikelnya maka luas permukaannya juga akan lebih besar sehingga permeabilitasnya terhadap sel akan lebih mudah (6).

Hasil yang diperoleh merupakan rasio perbandingan relatif terhadap kontrol positif $(100 \%$ hemolisis $)$ dan kontrol negatif ( $0 \%$ hemolisis). Jika dibandingkan dengan variasi volume nanopartikel dan dispersi $\mathrm{ZnSO}_{4}$ menunjukkan \% hemolisis yang terjadi pada variasi volume dan dispersi $\mathrm{ZnSO}_{4}$ tidak lebih besar dibandingkan dengan kontrol positif. Untuk kontrol negatif memiliki \% hemolisis sebesar $0 \%$ dikarenakan pada kontrol negatif digunakan larutan tyrod yang memiliki fungsi mempertahan sel dalam kisaran $\mathrm{pH}$ fisilogis, menjaga keseimbangan intraseluler dan ekstraseluler dan glukosa sebagai asupan energi untuk sel.

\section{KESIMPULAN}

Dari hasil penelitian dapat ditarik kesimpulan bahwa nanopartikel ZnS hasil reduksi bimatriks E. coli memberikan efek toksik terhadap sel darah merah.

\section{DAFTAR PUSTAKA}

1. Asha, P., Rajeswari, M. and Bindhu, B. 2016. Zinc sulfide nanoparticles : processing properties and applications : an overview, Journal of Chemcal and Pharmaceutical Sciences, 9(4), pp. 2047-2052.

2. Amily Fang-ju jou. dkk. 2015. Diagnosing the mir-141 prostate cancer biomarker using nucleic acid-functiolized cdSe/ZnS Qds and telomerase. Chemical science. 659-665

3. Sathishkumar, M. et al. 2017. characterization Antimicrobial activity of zinc sulphide nanoparticles and to study their characterization. Reasearch Gate

4. Durán, N. and Seabra, A. B. 2012. Microbial Syntheses of Metallic Sulfide Nanoparticles: An Overview', Current Biotechnology, Volume 1 Juni 2015), pp. 287-296. doi: 10.2174/2211550111201040287.

5. Dirgantarah, W. 2017. Studi Aplikasi Biomatriks Bakteri Escherichia Col Pada Produksi Quantum Dots Zink' Skrpsi tidak diterbitkan. Makassar Fakultas Farmasi Unhas.

6. Jackson, T. C., Patani, B. O. and Israel, M. B. 2017. Nanomaterials and Cell Interactions: A Review', Journal of Biomaterials and nanobiotechnology, pp. 220-228. doi: 10.4236/jbnb.2017.84015

7. Helle, M. et al. (2012) 'Visualisation of Sentinel Lymph Node with IndiumBased near Infrared Emitting Quantum Dots in a Murine Metastatic Breast Cancer Model', PLOS ONE, 7(8). doi: 10.1371/journal.pone.0044433.

8. Bogutska, K. I., Sklyarov, Y. P. and Prylutskyy, Y. I. 2013 .Zinc and zinc nanoparticles : biological role and application in biomedicine. Ucranica Bioorganica 9-16.

9. Rijas-Hernandez dkk. 2017. ZnS nanoparticles syhmtesised through chemical aggregation using polyetieneimene that works as boyh stabilizser and complexing agent. 